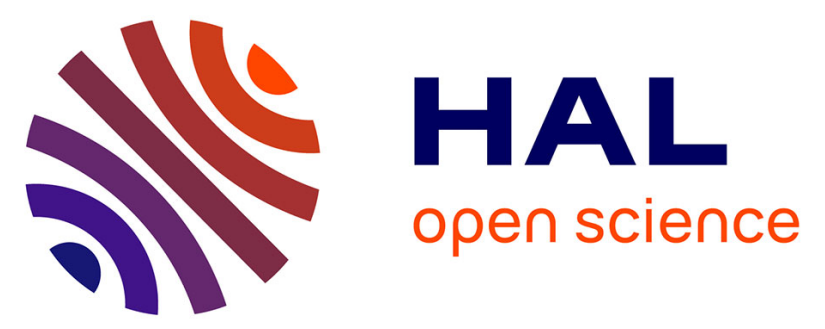

\title{
LARP7 variants and further delineation of the Alazami syndrome phenotypic spectrum among primordial dwarfisms: 2 sisters
}

Marion Imbert-Bouteille, Frédéric Tran Mau Them, Julien Thevenon, Thomas Guignard, Vincent Gatinois, Jean-Baptiste Rivière, Anne Boland, Vincent Meyer, Jean-François Deleuze, Elodie Sanchez, et al.

\section{To cite this version:}

Marion Imbert-Bouteille, Frédéric Tran Mau Them, Julien Thevenon, Thomas Guignard, Vincent Gatinois, et al.. LARP7 variants and further delineation of the Alazami syndrome phenotypic spectrum among primordial dwarfisms: 2 sisters. European Journal of Medical Genetics, 2019, 62 (3), pp.161-166. 10.1016/j.ejmg.2018.07.003 . hal-01845043

\section{HAL Id: hal-01845043 \\ https://hal.umontpellier.fr/hal-01845043}

Submitted on 25 Nov 2020

HAL is a multi-disciplinary open access archive for the deposit and dissemination of scientific research documents, whether they are published or not. The documents may come from teaching and research institutions in France or abroad, or from public or private research centers.
L'archive ouverte pluridisciplinaire HAL, est destinée au dépôt et à la diffusion de documents scientifiques de niveau recherche, publiés ou non, émanant des établissements d'enseignement et de recherche français ou étrangers, des laboratoires publics ou privés.

\section{(1)(1) $\$(0)$}

Distributed under a Creative Commons Attribution - NonCommercial - ShareAlikel 4.0 


\section{TITLE:}

$2 \quad L A R P 7$ Variants and Further Delineation of the Alazami Syndrome Phenotypic Spectrum

3 among Primordial Dwarfisms: 2 Sisters

4

\section{AUTHORS:}

6 Marion Imbert-Bouteille ${ }^{\mathrm{a}}$,

7 Frédéric Tran Mau Them ${ }^{\mathrm{a}, \mathrm{b}, \mathrm{c}, \mathrm{d}}$,

8 Julien Thevenon ${ }^{\mathrm{c}, \mathrm{d}, \mathrm{g}}$

9 Thomas Guignard ${ }^{\mathrm{a}}$,

10 Vincent Gatinois ${ }^{\mathrm{a}}$,

11 Jean-Baptiste Riviere ${ }^{\mathrm{e}}$,

Anne Boland ${ }^{\mathrm{f}}$

Vincent Meyer ${ }^{\mathrm{f}}$

Jean-François Deleuze ${ }^{\mathrm{f}}$

Elodie Sanchez ${ }^{\mathrm{a}, \mathrm{b}}$,

Florence Apparailly ${ }^{\mathrm{b}}$,

David Geneviève $e^{\mathrm{a}, \mathrm{b}}$,

Marjolaine Willems ${ }^{\mathrm{a}, \mathrm{b}}$.

a - Département de génétique médicale, maladies rares et médecine personnalisée, Centre de

21 référence anomalies du développement et syndromes malformatifs, Plateforme recherche de microremaniements chromosomiques, CHU de Montpellier, Université de Montpellier, b - Unité Inserm, U1183, Hôpital Saint-Eloi, CHU de Montpellier, Montpellier, France 
2

c - Equipe Génétique des Anomalies du Développement, INSERM UMR1231, Université de Bourgogne-Franche Comté,

d - Centre de Génétique et Centre de Référence Anomalies du Développement et Syndromes Malformatifs, FHU TRANSLAD, Hôpital d'Enfants, CHU Dijon et Université de Bourgogne, e - Laboratoire de Génétique Moléculaire, Plateau technique de Biologie - CHU Dijon, Dijon, France

f - Centre National de Génotypage, Institut de Génomique, Commissariat à l'Energie Atomique, Evry, France

g - Centre de génétique, Hôpital Couple-Enfant, CHU Grenoble-Alpes, La Tronche, France

Conflict of Interest: none declared

\section{CORRESPONDING AUTHOR:}

Marjolaine Willems

Département de Génétique Médicale, CHRU Arnaud de Villeneuve

371 avenue du doyen Gaston Giraud, 34000 Montpellier, France

Tel: +33(0)467336564

Fax: +33(0)4 67336052

Email: m-willems@chu-montpellier.fr 


\section{ABSTRACT}

Alazami syndrome (AS) (MIM\# 615071) is an autosomal recessive microcephalic primordial dwarfism (PD) with recognizable facial features and severe intellectual disability due to depletion or loss of function variants in LARP7. To date, 15 patients with AS have been reported. Here we describe two consanguineous Algerian sisters with Alazami PD due to LARP7 homozygous pathogenic variants detected by whole exome sequencing. By comparing these two additional cases with those previously reported, we strengthen the key features of AS: severe growth restriction, severe intellectual disability and some distinguishing facial features such as broad nose, malar hypoplasia, wide mouth, full lips and abnormally set teeth. We also report significant new findings enabling further delineation of this syndrome: disproportionately mild microcephaly, stereotypic hand wringing and severe anxiety, thickened skin over the hands and feet, and skeletal, eye and heart malformations. From previous reviews, we summarize the main etiologies of PD according to the involved mechanisms and cellular pathways, highlighting their clinical core features.

Keywords: Alazami syndrome; primordial dwarfism; LARP7; intellectual disability. 


\section{INTRODUCTION}

Primordial dwarfism (PD) encompasses a highly clinically and genetically heterogeneous group of disorders mainly characterized by severe pre- and post-natal growth retardation. More specifically, PD is defined by both height and weight being several standards of deviation (SD) below the age-adjusted mean and without major skeletal dysplasia(1).

Various molecular mechanisms underlie this group of disorders(2,3), including impaired mitotic mechanics(4-6), abnormal insulin-like growth factor 1 (IGF1) or 2 expression(7), abnormal response to DNA damage(8,9), defective spliceosomal machinery(10), abnormal replication licensing $(11,12)$, and transcriptional regulation abnormalities(13). The latter mechanism is involved with depletion or loss of function mutations of La RibonucleoProtein domain family 7 (LARP7, MIM\# 612026)(14). The LARP7 is a chaperone protein required for both stability and function of the RNA(15).

Pathogenic variants in LARP7 are responsible for Alazami syndrome (AS) (MIM\# 615071)(16), a recently described autosomal recessive PD associated with recognizable facial features and severe intellectual disability (ID). To date, 15 patients have been reported $(13,17-19)$.

Here, we describe two additional consanguineous Algerian sisters with Alazami PD due to LARP7 pathogenic variants. We strengthen some key features of AS and report significant new findings in comparison with previously reported cases to further delineate this syndrome. We focus on differences between AS and other PD disorders and suggest a simple diagram to map six main PD disorders, including AS, sorted by two core clinical features.

\section{MATERIAL AND METHODS}


The patients were referred for clinical suspicion of Rett syndrome without $\mathrm{MeCP} 2$ variant to the reference center for developmental anomalies at the University Hospital of Montpellier, France.

Written informed consent was obtained from the parents of both sisters for Whole Exome Sequencing (WES), as was consent for publication of this case report and photographs.

Genomic DNA was extracted from whole blood of the two affected children and their unaffected parents. Samples from one affected child (patient 1) and her mother underwent WES performed by the Centre National de Génotypage, Institut de Génomique, Commissariat à l'Energie Atomique. After complete DNA quality control (quantification in duplicate, DNA integrity evaluation, absence of PCR inhibitors verification), genomic DNA ( $3 \mu \mathrm{g})$ was captured by an in-solution enrichment method (Human All Exon v5 - $50 \mathrm{Mb}$, Agilent Technologies, Santa Clara, CA, USA). Library preparation and exome enrichment ( 20.000 targeted genes) was performed automatically by using NGSx (Perkin Elmer, MA, USA) and Bravo (Agilent Technologies, CA, USA), respectively, according to the manufacturer's instructions (SureSelect, Agilent Technologies CA, USA). After normalisation and quality control, exome-enriched libraries were sequenced by using the Illumina HiSeq2000 system (Illumina, CA, USA) as paired-end 100-bp reads. Samples were sequenced as pools of 4 samples per lane, to obtain an average coverage of 70 to $80 \mathrm{X}$, with at least $80 \%$ of the target nucleotides covered at $30 \mathrm{X}$. Image analysis and base-calling involved use of the Illumina Real Time Analysis (RTA) Pipeline. Sequence-quality parameters were assessed daily during the 12 days of sequencing. Standard bioinformatics analysis of sequencing data was based on the Illumina pipeline (CASAVA1.8.2) to generate a FASTQ file for each sample. Reads were mapped against the genomic sequences (human genome version hg19) of the targeted genes with the alignment algorithm ELANDv2 (multiseed and gapped alignments). Genetic variation annotation and filtration involved use of the Dijon in-house pipeline, as recently 
described in Nambot et al.(20) To further filter out the variants, we applied one set of criteria: "gene known to be related to a human disease in OMIM database (table S1: column I)" and "allele frequence $<0.01$ in all public databases ESP, ExAC, GnomAD" (table S1: columns O to R)". We analyzed each survived variant after filtration through its biological consistency and phenotypic relevance. Candidate variant and familial segregation were confirmed by Sanger sequencing for both affected sisters (patients 1 and 2) and each parent.

\section{PATIENT REPORTS}

\section{Patients 1 and 2}

The sisters were the only children of consanguineous Algerian parents. The family history was negative. Both pregnancies were uneventful but without medical follow-up. Both sisters were born at term, at home. Birth measurements were not reported. The sisters did not present feeding difficulties in infancy. Clinical examination was performed when the sisters were age 26 and 22. Clinical features are summarized and compared with previously reported patient features in Table 1.

Both sisters presented severe growth retardation and disproportionate mild microcephaly: occipitofrontal circumference (OFC) decrease was less severe than height decrease (at least 2 SD discrepancy between OFC and height) (Table 1). Both presented severe ID, including absence of speech. They did not recognize known people from unknown people. They both presented a severe anxiety. They had autistic behaviors such as stereotypic hand wringing, but gripping and handling were possible (Figure 1a). Both had lower-limb spasticity and increased tendon reflexes. Upper-limb joint mobility (wrist and elbow) was abnormally decreased.

The sisters had poor appetite, very selective eating behavior (almost exclusively dairy products) and chronic constipation. Physical examination revealed facial features in both (Figure 1b). They featured proximally placed fourth toes and thumbs (Figure 2a), thickened 
skin over the hands (Figure 1c) and feet and cutis marmorata (Figure 1d). Pubertal development milestones were normal for both sisters (first periods at age 12).

\section{Patient 1}

In addition to the facial features shared with her sister, patient 1 presented sparse eyebrows, narrow and short palpebral fissures with deep-set eyes, a bifid tip on the nose and a short philtrum. She had neurosensorial disability, with low vision on left side and a keratoconus on the right eye, which caused blindness on this side. She needed a Botox injection to treat the spasticity. She had experienced tonicoclonic seizures at age 6 and received valproate for 1 year. She could smile. Daytime toilet training was achieved at age 4.

\section{Patient 2}

Patient 2 began to walk at age 3 and a half. Toilet training was never achieved. She could not smile.

\section{Paraclinical investigations}

Skeletal X-rays showed slender bones with increased cortical thickness (Figure 2b), a thin calvarium with low-density skullcap, fingerprint marks (Figure 2c) and high vertebrae with small intervertebral disks.

Metabolic screening and micro-array comparative genomic hybridization findings were unremarkable. Molecular genetic study was negative for genes involved in Rett Syndrome (MIM\#312750)(21), congenital variant of Rett Syndrome (MIM\#613454)(22) and Early Infantile Epileptic Encephalopathy type 2 (MIM\#300672)(23)(MeCP2, FOXG1 and CDKL5, respectively) as was chromosome breakage study. Brain MRI was normal but CT-scan revealed small brains without calcification. Abdominal and renal ultrasonography findings were normal. Otoacoustic emissions were normal.

\section{RESULTS}


On WES, patient 1 showed a homozygous frameshift variant in exon 7 of LARP7: c.524_525insTT (p.(Ala176Leufs*37)) (NM_001267039.1 ; SCV000743091). This homozygous variant was confirmed in both sisters. Each parent was heterozygous for this LARP7 variant.

Because the $L A R P 7$ variant is a frameshift variant in a gene whose loss of function is a known mechanism of disease, totally absent from controls in population databases (Exome Sequencing Project, 1000 Genomes Project and Genome Aggregation Database), detected as homozygous for this recessive disorder, we classified this variant as pathogenic with a strong level of evidence.(24)

After filtration strategy, 124 variants were left (listed in table S1), including 50 variants in genes known to be related to an autosomal dominant disease and 74 variants in genes known to be related to an autosomal recessive disease.

\section{DISCUSSION}

AS was defined by Alazami et al. in 2012(13) as a novel autosomal-recessive PD syndrome characterized by severe growth restriction with onset at birth and severe ID, related to pathogenic variants in $L A R P 7$. The original phenotypic spectrum has been expanded and includes recognizable facial features, such as triangular face, prominent forehead, deep-set eyes, sparse eyebrows, broad nose, widely spaced teeth and wide mouth(19) and behavioral concerns such as anxiety and hypersensitivity to hearing stimuli(18).

We report two new patients with AS. They strengthen previous descriptions because our patients share several key features with those in the literature: severe growth restriction and some distinguishing facial features. They highlight the facial pattern (including broad nose, malar hypoplasia, wide mouth and abnormally set teeth) as a core feature of AS. However, we highlight some additional features that are summarized in Table 1. 
The discrepancy between height and OFC decrease severity is noteworthy and observed in all patients previously reported. This suggests that mild, even absent, microcephaly may fully match AS. This feature clearly differentiates AS from other microcephalic PDs such as Seckel syndrome and Microcephalic Osteodysplastic Primordial Dwarfisms (MOPDs)(5,28).

Our patients present potentially misleading behavioral diagnostic features: Rett-like stereotypical hand wringing and severe anxiety. In addition to other behavioral concerns previously described, these features seem to be entirely part of the phenotypic spectrum of AS. Interestingly for the categorization among other PD, these behavioral features clearly differentiated from Meier-Gorlin and Silver-Russel syndromes(11,29,30).

Cutis marmorata, seen in other PDs such as MOPD type 2, has never been reported and seems rare in AS, whereas thickened skin over the hands and feet appears more frequent and could be a recognizable physical sign (Figure 1c).

The skeletal (slender bones with increased cortical thickness and abnormally set toes and fingers), eye (keratoconus) and heart (atrial septal defect) malformations are remarkable and could be searched in other AS patients.

We suggest that these additional clinical findings belong to the AS phenotypic spectrum considering that they are in the overlapping part of the two sisters phenotypes. It could be interesting to further investigate all previously reported patients with AS in order to confirm the presence or absence of these apparently novel findings.

Nevertheless, multiple diagnosis is reported in about $1.4 \%$ to $7.2 \%$ of patients with complex phenotypes who undergo WES(31). Furthermore, prospective annual reanalysis of WES has been showed to improve diagnostic yield, highlighting that truly pathogenic variants can be missed by WES(20). Thus, we could not completely exclude the possibility of a multiple molecular diagnosis in these siblings that would have not been identified by WES at time of analyzing. It could also be argued that one or several other potentially modifier variants 
detected in the WES might contribute to these additional finding. In this regard, we carefully analyzed all survived variants and attempted to identify those which could be relevant candidate as potentially modifying the causing variant. Among all 124 variants listed in table S1, none had both sufficient biological consistency and phenotypic relevance to be pointed out.

Figure 3, based on previous reviews $(1,2,32)$ summarizes the main etiologies of PD: Seckel syndrome, MOPDs, Meier-Gorlin syndrome, IGF1 and IGF1-receptor deficiency syndromes, Silver-Russel syndrome and AS. In an attempt to map AS and these different syndromes in a practical simple manner, we present a streamlined diagram sorted by two core features: ID and microcephaly severity. We mentioned as well the involved mechanisms and cellular pathways. In this regard, AS is a PD with severe ID and mild microcephaly or normal OFC and an LARP7-related syndrome involving transcriptional regulation abnormalities. MOPD and Seckel syndrome both are PDs with severe ID and severe microcephaly. Both MOPD and Seckel syndrome may be linked to an abnormal mitosis and are part of the Centromeric Protein J- and Pericentrin-related syndromes. MOPD may also be linked to a defective spliceosomal machinery and is an RNU4ATAC-related syndrome. Seckel syndrome may also be linked to a perturbed DNA damage response and is part of the ATR-, ATRIP- and RBBP8related Seckel syndromes. Meier-Gorlin syndrome and IGF1 and IGF1-receptor deficiency syndromes are both PDs with severe microcephaly and normal cognitive development (CD) or mild ID, related to abnormal replication licensing and abnormal GH-IGF1 signaling, respectively. Silver-Russel syndrome is a PD with normal or subnormal CD and normal OFC due to abnormal IGF2 expression.

In conclusion, we suggest further delineation of the AS phenotypic spectrum, which includes PD with possibly disproportionate mild even absent microcephaly, commonly severe ID, some recognizable facial and skeletal features and frequent behavioral autistic or Rett-like 
232 features. This delineation might be helpful for the clinical diagnosis process, including for

233 "WES as a first-line test and back to phenotype" approach.

234 ACKNOWLEDGMENTS:

235 We thank the patients and their family for letting us share their medical data with the 236 scientific community. We thank Laura Smales for valuable editorial assistance. 
a. Behavioral pictures at age 26 and 22, respectively (upper left picture), and age 24 (upper right picture). Both presented autistic behaviors such as stereotypic hand wringing.

b. Front, lateral and global views at age 21 (patient 1) and 17 years (patient 2). Both presented facial features: broad nose, malar hypoplasia, wide mouth, full lips and abnormally set teeth. This pattern of facial features is shared with most patients with Alazami syndrome previously reported. It highlights this facial pattern as a core feature of Alazami syndrome. In addition, patient 1 presented sparse eyebrows, narrow and short palpebral fissures with deep-set eyes, a bifid tip of nose and a short philtrum. Note disproportionate mild microcephaly compared with severe short stature.

c. Palmar side of hands: both sisters presented thickened skin over the hands (and feet, not shown).

d. Skin pictures: both sisters presented extended cutis marmorata.

Figure 2: Skeletal features and $X$-rays views.

a. Both sisters presented abnormally set fourth toes and proximally set thumbs (left upper pictures).

b. Skeletal X-rays showing slender bones (black arrows) with increased cortical thickness (pairs of white arrows). Only patient $2 \mathrm{X}$-rays are shown (lower pictures), from left to right: front views of the hips, left knee, left forearm and right arm. c. Head X-rays showing a thin calvarium with low-density skullcap and fingerprint marks (white arrows). Only patient $2 \mathrm{X}$-rays are shown.

Figure 3: Main etiologies of primordial dwarfism (PDs) according to two core features and linked to the involved mechanisms and cellular pathways. As an example, Microcephalic Osteodysplastic Primordial Dwarfisms (MOPDs) and Seckel syndrome both are PDs with severe intellectual disability and severe MC. Both MOPDs and Seckel syndrome may be linked to abnormal mitosis and are part of the Centomeric Protein Jand Pericentrin-related syndromes. MOPD may also be linked to a defective spliceosomal machinery and is an RNU4ATAC-related syndrome. Seckel syndrome may also be linked to a perturbed DNA damage response and is part of the ATR-, ATRIP- and RBBP8-related Seckel syndromes. For further description of this figure, see the Discussion. PD: primordial dwarfism, ID: intellectual disability, CD: cognitive development, $M C$ : microcephaly, OFC: occipito-frontal circumference, MOPD: Microcephalic Osteodyplastic Primordial Dwarfism. 
Table 1. Comparison of clinical features of presented patients and previously reported

272 patients with Alazami syndrome.

\begin{tabular}{|c|c|c|c|c|c|c|c|}
\hline & $\begin{array}{l}\text { Alazami } e t \\
\text { al. (13) }\end{array}$ & $\begin{array}{l}\text { Najmabadi } e t \\
\text { al.(17) }\end{array}$ & $\begin{array}{l}\text { Ling } \text { et } \\
\text { al.(18) }\end{array}$ & $\begin{array}{l}\text { Hollink et } \\
\text { al.(19) }\end{array}$ & $\begin{array}{c}\text { Patient } \\
1\end{array}$ & $\begin{array}{c}\text { Patient } \\
2 \\
\end{array}$ & Total \\
\hline $\begin{array}{l}\text { ID } \\
\text { (severe) }\end{array}$ & $10 / 10$ & $2 / 2$ & $1 / 1$ & $2 / 2$ & $\begin{array}{l}\text { Yes } \\
\text { (No } \\
\text { speech) }\end{array}$ & $\begin{array}{l}\text { Yes } \\
\text { (No } \\
\text { speech) }\end{array}$ & $17 / 17$ \\
\hline \multicolumn{8}{|l|}{ Biometry } \\
\hline Weight (SD) & -2 to -4.5 & NR & $-5,5$ & -1 to -3 & -2.8 & -3.5 & NC \\
\hline Height (SD) & -4 to -10.5 & $\mathrm{NR}$ & -4 & -2.5 to -3 & -6.5 & -6.8 & $\mathrm{NC}$ \\
\hline$\overline{\mathrm{OFC}}(\mathrm{SD})$ & -1.5 to -7 & $<-2$ & -1 & -2 to -4 & -3.5 & -3.5 & $\mathrm{NC}$ \\
\hline DMM & $8 / 9$ & $\mathrm{NR}$ & $1 / 1$ & $0 / 2$ & + & + & $11 / 14$ \\
\hline \multicolumn{8}{|l|}{ Facial features } \\
\hline Triangular face & $9 / 9$ & NR & $1 / 1$ & $1 / 2$ & - & - & $11 / 14$ \\
\hline $\begin{array}{l}\text { Prominent } \\
\text { forehead }\end{array}$ & $+(\mathrm{NC})$ & $\mathrm{NR}$ & $1 / 1$ & $2 / 2$ & - & - & $\mathrm{NC}$ \\
\hline $\begin{array}{l}\text { Narrow and short } \\
\text { palpebral fissures }\end{array}$ & $7 / 9$ & NR & $0 / 1$ & $1 / 2$ & + & - & $8 / 14$ \\
\hline Deep-set eyes & $9 / 9$ & $\mathrm{NR}$ & $1 / 1$ & $2 / 2$ & + & - & $12 / 14$ \\
\hline Sparse eyebrows & $9 / 9$ & NR & $0 / 1$ & $1 / 2$ & + & - & $11 / 14$ \\
\hline Low set ears & $6 / 9$ & NR & $1 / 1$ & $0 / 2$ & - & - & $7 / 14$ \\
\hline Malar hypoplasia & $8 / 9$ & $\mathrm{NR}$ & $1 / 1$ & $1 / 2$ & - & + & $10 / 14$ \\
\hline Broad nose & $9 / 9$ & $\mathrm{NR}$ & $0 / 1$ & $2 / 2$ & + & + & $12 / 14$ \\
\hline Short philtrum & $9 / 9$ & $\mathrm{NR}$ & $0 / 1$ & $1 / 2$ & + & - & $11 / 14$ \\
\hline Wide mouth & 9/9 & NR & $1 / 1$ & $1 / 2$ & + & + & $13 / 14$ \\
\hline Full lips & $5 / 9$ & NR & $1 / 1$ & $2 / 2$ & + & + & $10 / 14$ \\
\hline $\begin{array}{l}\text { Widely spaced } \\
\text { teeth/tooth } \\
\text { misalignment }\end{array}$ & $8 / 9$ & NR & $1 / 1$ & $2 / 2$ & + & + & $13 / 14$ \\
\hline \multicolumn{8}{|c|}{ Skeletal, muscle and skin features } \\
\hline Scoliosis & $2 / 9$ & $\mathrm{NR}$ & NR & $1 / 2$ & + & - & $4 / 13$ \\
\hline $\begin{array}{l}\text { Hypermobility of } \\
\text { distal tips }\end{array}$ & NR & $\mathrm{NR}$ & $0 / 1$ & $1 / 2$ & + & - & $2 / 5$ \\
\hline $\begin{array}{l}\text { Abnormally set } \\
\text { toe(s)/fingers }\end{array}$ & NR & NR & $0 / 1$ & $1 / 2$ & + & + & $3 / 5$ \\
\hline Skeletal anomalies & NR & NR & $0 / 1$ & $1 / 2$ & + & + & $3 / 5$ \\
\hline $\begin{array}{l}\text { Thickened skin } \\
\text { over the hands and } \\
\text { feet }\end{array}$ & $5 / 9$ & NR & $0 / 1$ & $1 / 2$ & + & + & $8 / 14$ \\
\hline Cutis marmorata & NR & NR & $0 / 1$ & $0 / 2$ & + & + & $2 / 5$ \\
\hline \multicolumn{8}{|l|}{ Behavioral features } \\
\hline Anxiety & NR & NR & $1 / 1$ & $1 / 2$ & - & - & $2 / 5$ \\
\hline $\begin{array}{l}\text { Self-mutilation of } \\
\text { hands }\end{array}$ & $2 / 9$ & NR & $1 / 1$ & & - & - & $3 / 12$ \\
\hline Stereotypic & NR & NR & $0 / 1$ & $0 / 2$ & + & + & $2 / 5$ \\
\hline
\end{tabular}


behavior including hand wringing

\begin{tabular}{|c|c|c|c|c|c|c|c|}
\hline $\begin{array}{l}\text { Selective eating } \\
\text { behavior }\end{array}$ & NR & NR & $0 / 1$ & $0 / 2$ & + & + & $2 / 5$ \\
\hline \multicolumn{8}{|l|}{ Other features } \\
\hline Seizures & NR & NR & $0 / 1$ & $0 / 2$ & + & - & $1 / 5$ \\
\hline Ocular anomalies & NR & NR & $0 / 1$ & $0 / 2$ & - & $+*$ & $1 / 5$ \\
\hline Strabismus & $4 / 9$ & NR & $0 / 1$ & $0 / 2$ & - & - & $4 / 14$ \\
\hline Atrial septal defect & NR & NR & $0 / 1$ & $0 / 2$ & - & + & $1 / 5$ \\
\hline $\begin{array}{l}\text { Disturbed } \\
\text { sleep/sleep apnea } \\
\text { episodes }\end{array}$ & NR & NR & $0 / 1$ & $0 / 2$ & + & + & $2 / 5$ \\
\hline
\end{tabular}




\section{REFERENCES ( 25 \& 6 OMIM Numbers)}

1. Alkuraya FS. Primordial dwarfism: an update. Curr Opin Endocrinol Diabetes Obes. 2015 Feb 1;22(1):55-64.

2. Klingseisen A, Jackson AP. Mechanisms and pathways of growth failure in primordial dwarfism. Genes Dev. 2011 Oct 1;25(19):2011-24.

3. Shaheen R, Faqeih E, Ansari S, Abdel-Salam G, Al-Hassnan ZN, Al-Shidi T, et al. Genomic analysis of primordial dwarfism reveals novel disease genes. Genome Res. 2014 Feb;24(2):291-9.

4. Koparir A, Karatas OF, Yuceturk B, Yuksel B, Bayrak AO, Gerdan OF, et al. Novel POC1A mutation in primordial dwarfism reveals new insights for centriole biogenesis. Hum Mol Genet. 2015 Oct 1;24(19):5378-87.

5. Willems M, Geneviève D, Borck G, Baumann C, Baujat G, Bieth E, et al. Molecular analysis of pericentrin gene (PCNT) in a series of 24 Seckel/microcephalic osteodysplastic primordial dwarfism type II (MOPD II) families. J Med Genet. 2010 Dec;47(12):797-802.

6. Martin C-A, Ahmad I, Klingseisen A, Hussain MS, Bicknell LS, Leitch A, et al. Mutations in PLK4, encoding a master regulator of centriole biogenesis, cause microcephaly, growth failure and retinopathy. Nat Genet. 2014 Dec;46(12):1283.

7. Wit JM, Oostdijk W, Losekoot M, van Duyvenvoorde HA, Ruivenkamp CAL, Kant SG. MECHANISMS IN ENDOCRINOLOGY: Novel genetic causes of short stature. Eur J Endocrinol. 2016 Apr;174(4):R145-173.

8. Ogi T, Walker S, Stiff T, Hobson E, Limsirichaikul S, Carpenter G, et al. Identification of the first ATRIP-deficient patient and novel mutations in ATR define a clinical spectrum for ATR-ATRIP Seckel Syndrome. PLoS Genet. 2012;8(11):e1002945.

9. Murray JE, van der Burg M, IJspeert H, Carroll P, Wu Q, Ochi T, et al. Mutations in the NHEJ component XRCC4 cause primordial dwarfism. Am J Hum Genet. 2015 Mar $5 ; 96(3): 412-24$.

10. Edery P, Marcaillou C, Sahbatou M, Labalme A, Chastang J, Touraine R, et al. Association of TALS developmental disorder with defect in minor splicing component U4atac snRNA. Science. 2011 Apr 8;332(6026):240-3.

11. Kerzendorfer C, Colnaghi R, Abramowicz I, Carpenter G, O'Driscoll M. Meier-Gorlin syndrome and Wolf-Hirschhorn syndrome: two developmental disorders highlighting the importance of efficient DNA replication for normal development and neurogenesis. DNA Repair. 2013 Aug;12(8):637-44.

12. Reynolds JJ, Bicknell LS, Carroll P, Higgs MR, Shaheen R, Murray JE, et al. Mutations in DONSON disrupt replication fork stability and cause microcephalic dwarfism. Nat Genet. 2017 Apr;49(4):537-49. 
13. Alazami AM, Al-Owain M, Alzahrani F, Shuaib T, Al-Shamrani H, Al-Falki YH, et al. Loss of function mutation in LARP7, chaperone of 7SK ncRNA, causes a syndrome of facial dysmorphism, intellectual disability, and primordial dwarfism. Hum Mutat. 2012 Oct 1;33(10):1429-34.

\section{OMIM Entry - *612026 - La RIBONUCLEOPROTEIN DOMAIN FAMILY,} MEMBER 7; LARP7 [Internet]. [cited 2017 Jul 11]. Available from: https://www.omim.org/entry/612026

15. Xu L, Kong R, Zhu J, Sun H, Chang S. Unraveling the conformational determinants of LARP7 and 7SK small nuclear RNA by theoretical approaches. Mol Biosyst. 2016 Jul 19;12(8):2613-21.

16. OMIM Entry - \# 615071 - ALAZAMI SYNDROME; ALAZS [Internet]. [cited 2016 Sep 12]. Available from: http://www.omim.org/entry/615071

17. Najmabadi H, Hu H, Garshasbi M, Zemojtel T, Abedini SS, Chen W, et al. Deep sequencing reveals 50 novel genes for recessive cognitive disorders. Nature. 2011 Oct 6;478(7367):57-63.

18. Ling TT, Sorrentino S. Compound heterozygous variants in the LARP7 gene as a cause of Alazami syndrome in a Caucasian female with significant failure to thrive, short stature, and developmental disability. Am J Med Genet A. 2016 Jan 1;170(1):217-9.

19. Hollink IH, Alfadhel M, Al-Wakeel AS, Ababneh F, Pfundt R, de Man SA, et al. Broadening the phenotypic spectrum of pathogenic LARP7 variants: two cases with intellectual disability, variable growth retardation and distinct facial features. J Hum Genet. 2016 Mar;61(3):229-33.

20. Nambot S, Thevenon J, Kuentz P, Duffourd Y, Tisserant E, Bruel A-L, et al. Clinical whole-exome sequencing for the diagnosis of rare disorders with congenital anomalies and/or intellectual disability: substantial interest of prospective annual reanalysis. Genet Med Off J Am Coll Med Genet. 2 nov 2017.

21. OMIM Entry - \# 312750 - RETT SYNDROME; RTT [Internet]. [cited 2017 Jul 11]. Available from: https://www.omim.org/entry/312750?search=rett\%20syndrome\&highlight=syndromic\%20syn drome\%20rett

\section{OMIM Entry - \# 613454 - RETT SYNDROME, CONGENITAL VARIANT} [Internet]. [cited 2017 Jul 11]. Available from: https://www.omim.org/entry/613454?search=congenital\%20variant\%20of\%20rett\%20syndro me\&highlight=congenital\%20syndrome $\% 20$ of\%20rett\%20variant $\% 20$ syndromic

23. OMIM Entry - \# 300672 - EPILEPTIC ENCEPHALOPATHY, EARLY INFANTILE, 2; EIEE2 [Internet]. [cited 2017 Jul 11]. Available from: https://www.omim.org/entry/300672 
Guidelines for the Interpretation of Sequence Variants: A Joint Consensus Recommendation of the American College of Medical Genetics and Genomics and the Association for Molecular Pathology. Genet Med Off J Am Coll Med Genet. 2015 May;17(5):405-24.

25. OMIM Entry - \# 617600 - MENTAL RETARDATION, AUTOSOMAL DOMINANT 45; MRD45 [Internet]. [cité 30 avr 2018]. Disponible sur: https://www.omim.org/entry/617600

26. Lu H-C, Tan Q, Rousseaux MWC, Wang W, Kim J-Y, Richman R, et al. Disruption of the ATXN1-CIC complex causes a spectrum of neurobehavioral phenotypes in mice and humans. Nat Genet. avr 2017;49(4):527-36.

27. Vissers LELM, Ligt J de, Gilissen C, Janssen I, Steehouwer M, Vries P de, et al. A de novo paradigm for mental retardation. Nat Genet. déc 2010;42(12):1109-12.

28. Verloes A, Drunat S, Gressens P, Passemard S. Primary Autosomal Recessive Microcephalies and Seckel Syndrome Spectrum Disorders. In: Pagon RA, Adam MP, Ardinger HH, Wallace SE, Amemiya A, Bean LJ, et al., editors. GeneReviews(®) [Internet]. Seattle (WA): University of Washington, Seattle; 1993 [cited 2017 Jul 11]. Available from: http://www.ncbi.nlm.nih.gov/books/NBK9587/

29. de Munnik SA, Hoefsloot EH, Roukema J, Schoots J, Knoers NVAM, Brunner HG, et al. Meier-Gorlin syndrome. Orphanet J Rare Dis. 2015 Sep 17;10:114.

30. Wakeling EL, Brioude F, Lokulo-Sodipe O, O'Connell SM, Salem J, Bliek J, et al. Diagnosis and management of Silver-Russell syndrome: first international consensus statement. Nat Rev Endocrinol. 2017 Feb;13(2):105-24.

31. Balci TB, Hartley T, Xi Y, Dyment DA, Beaulieu CL, Bernier FP, et al. Debunking Occam's razor: Diagnosing multiple genetic diseases in families by whole-exome sequencing. Clin Genet. sept 2017;92(3):281 $\square$ 9.

32. Khetarpal P, Das S, Panigrahi I, Munshi A. Primordial dwarfism: overview of clinical and genetic aspects. Mol Genet Genomics. 2016 Feb 1;291(1):1-15.

\section{Supplemental data:}

Table S1: List of all survived variants after filtration strategy (lines 3 to 52: variants in genes related to an autosomal dominant disease; lines 53 to 126: variants in genes related to an autosomal recessive disease).

See Excel table S1 attached 

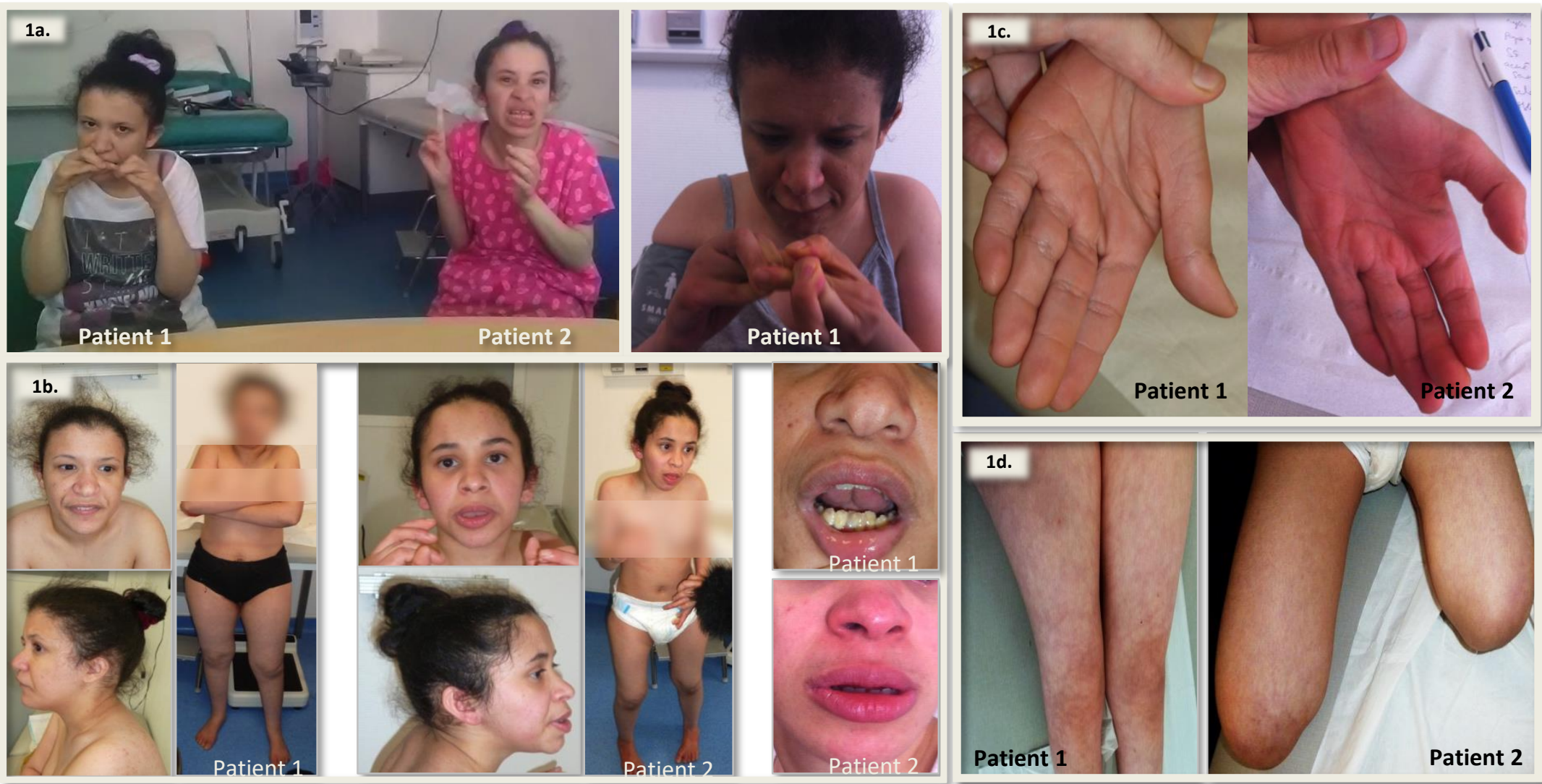

Figure 1: Patients 1 and 2: clinical features.

a. Behavorial pictures at age 26 and 22, respectively (upper left picture), and age 24 (upper right picture). Both presented autistic behaviors such as stereotypic hand wringing.

b. Front, lateral and global views at age 21 (patient 1) and 17 years (patient 2). Both presented facial features: broad nose, malar hypoplasia, wide mouth, full lips and abnormally set teeth. This pattern of facial features is shared with most patients with Alazami syndrome previously reported. It highlights this facial pattern as a core feature of Alazami syndrome. In addition, patient 1 presented sparse eyebrows, narrow and short palpebral fissures with deep-set eyes, a bifid tip of nose and a short philtrum. Note disproportionate mild microcephaly compared with severe short stature. c. Palmar side of hands: both sisters presented thickened skin over the hands (and feet, not shown).

d. Skin pictures: both sisters presented extended cutis marmorata. 

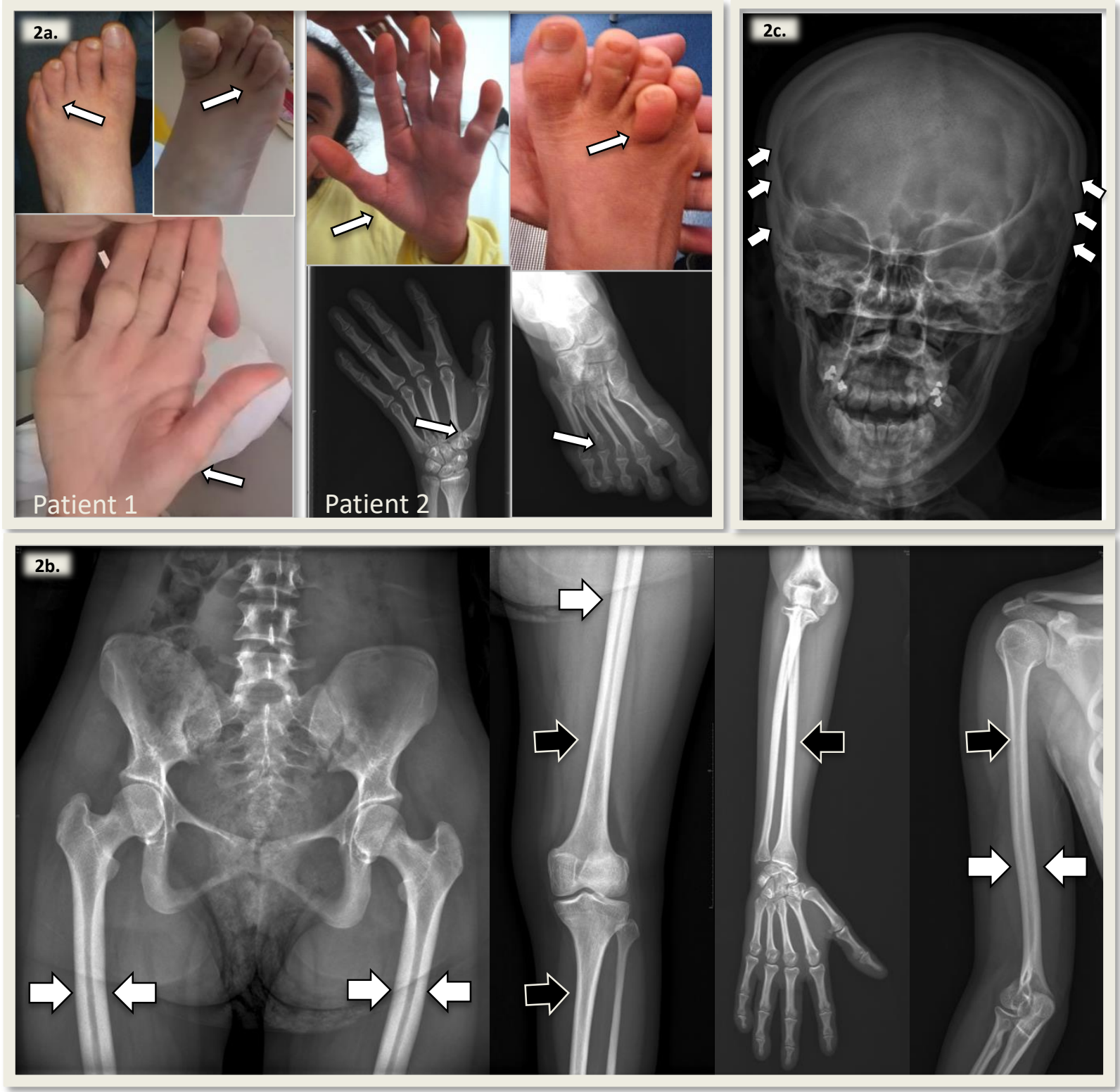

Figure 2: Skeletal features and X-rays views.

a. Both sisters presented abnormally set fourth toes and proximally set thumbs (left upper pictures).

b. Skeletal X-rays showing slender bones (black arrows) with increased cortical thickness (pairs of white arrows).

Only patient $\mathbf{2} \mathrm{X}$-rays are shown (lower pictures), from left to right: front views of the hips, left knee, left forearm and right arm.

c. Head X-rays showing a thin calvarium with low-density skullcap and fingerprint marks (white arrows). Only patient $2 \mathrm{X}$-rays are shown. 
Transcriptional

regulation

abnormalities LARP7-related syndrome

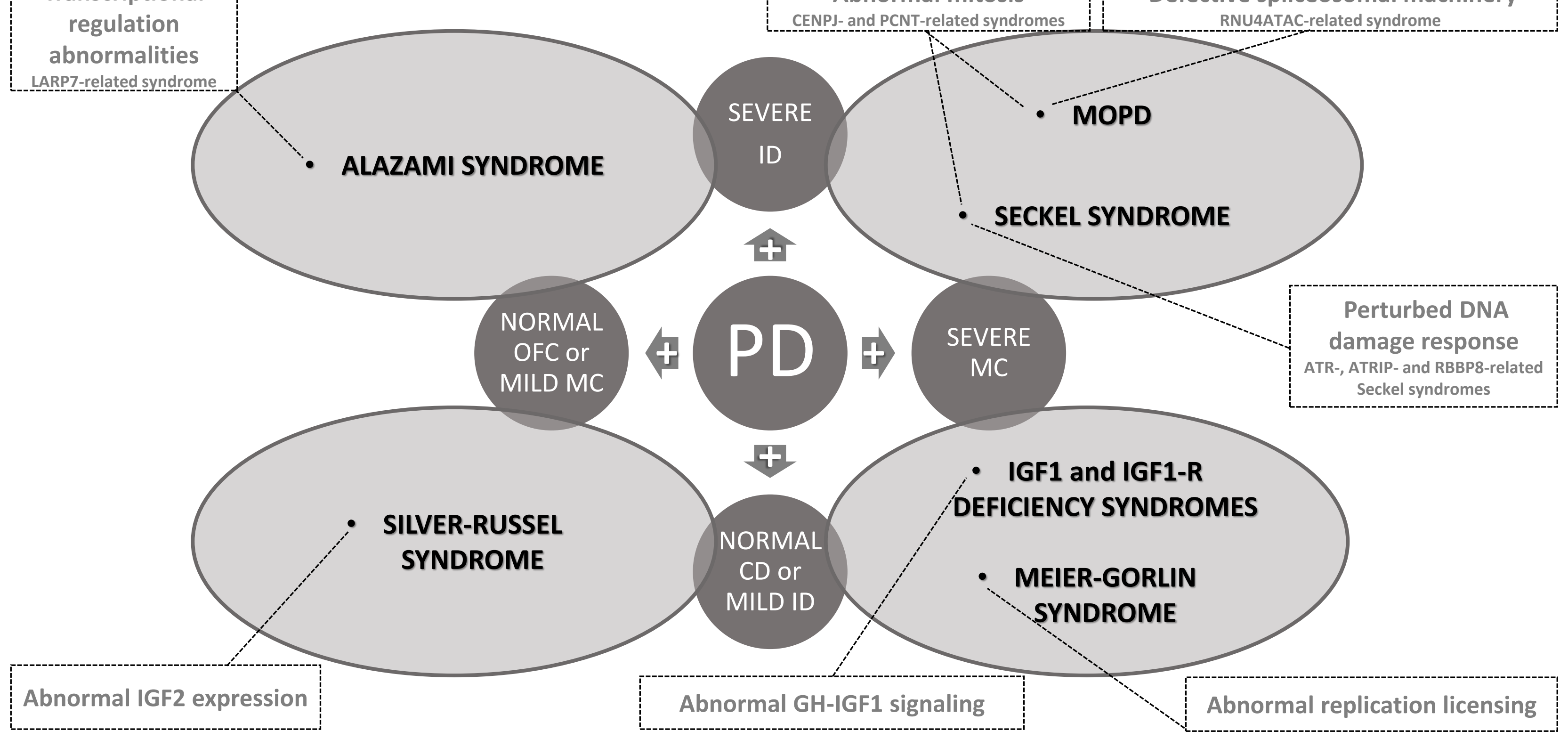

Figure 3: Main etiologies of primordial dwarfism sorted with two core-features and linked to the involved mechanisms and cellular pathways.

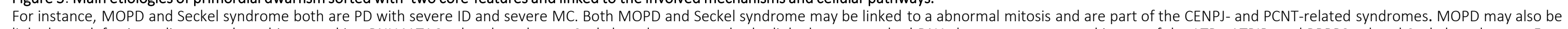

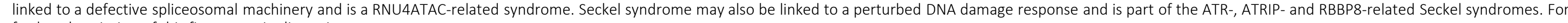
further description of this figure, see in discussion.

PD: primordial dwarfism, ID: intellectual disability, CD: cognitive development, MC: microcephaly, OFC: occipito-frontal circumference, MOPD: Microcephalic Osteodyplastic Primordial Dwarfism. 